Alicante Journal of English Studies 27(2014): 91-105

\title{
Lexical innovation: cromulently embiggening a language
}

\author{
Ian MacKenzie \\ University of Geneva \\ ian.mackenzie@unige.ch
}

\begin{abstract}
In this article I look at the main ways of making new English words, and at the different types of neologisms this produces; consider various categories of people who coin them, including famous authors and television scriptwriters as well as anonymous nonnative speakers of English as a lingua franca, and highlight the similarities and differences in the ways they tend to coin words; consider to what extent the formation of new words by way of established processes or rules or schemas should be thought of as morphological productivity rather than individual creativity; and finally look at the processes by which neologisms can, potentially, be diffused.
\end{abstract}

Keywords: lexical innovation, neologisms, morphological productivity, lexical creativity, lexical diffusion

For last year's words belong to last year's language And next year's words await another voice. (T. S. Eliot, "Little Gidding")

Inventing new words is easy: anyone can do it, and perhaps everybody does. For example, with very little thought, most readers of this journal could rapidly come up with new words ending in -ness, -able, -phile, -phobe, and -itis. What is more difficult, of course, is getting other people to use your coinages, thereby cromulently embiggening a language. I will begin this article by describing the main ways of making new English words, giving examples of the different types of neologisms this produces. I will then consider various categories of people who coin them, including famous literary authors and television scriptwriters, as well as anonymous nonnative speakers of English as a lingua franca, and look at the similarities and differences in the 
processes they tend to use to coin words, before considering whether forming new words by way of established processes or rules or schemas should be thought of in terms of individual creativity or merely morphological or constructional productivity, before finally briefly looking at the processes by which neologisms get diffused - or not.

\section{How?}

There is a Calvin and Hobbes cartoon, reproduced in Steven Pinker's The Stuff of Thought (2008: 15), in which the six-year-old Calvin (who clearly went to a better school than I did) takes a physics exam. Faced with the instruction "Explain Newton's First Law of Motion in your own words," he writes "Yakka foob mog. Grug pubbawup zink wattoom gazork. Chumble spuzz"! Inventing words is as easy as that, but of course most of Calvin's attempts don't sound very English: while not phonotactically impossible, yakka and pubbawup and wattoom do not resemble English words, taking 'English' generously to include bits of Anglo-Saxon, Norse, French, Latin and Greek. Unless they are borrowed from afar - amok, bikini, gung ho, karaoke, kow-tow, tattoo, tycoon - new English words generally sound much like existing ones, or simply combine parts of other English words and affixes. In fact, given that there are a limited number of English-sounding phonemes and morphemes and syllables to go round, newly coined words often turn out to have existed before. For example, long before Tolkien (1937) invented the Hobbits - hole-dwelling, human-like 'halflings' - hobbit was (one spelling of) a small basket for carrying seeds and a local measure of grain (2 $1 / 2$ bushels, to be precise) in North Wales. And halfling, an adverb meaning "to the extent of a half, half; in part, partially" (The Oxford English Dictionary, hereafter OED) goes back to 13th century Middle English (as Tolkien certainly knew). Similarly, J. K. Rowling's (1997) Muggles - those of us sadly lacking magical powers - were preceded by muggle meaning "a tail resembling that of a fish" (13th century); "a young woman, specifically a sweetheart" (16th century, possibly a corruption of the Italian moglie, wife); and in the 20th century in the USA, a joint or marijuana cigarette (smoked by muggle-heads).

Leaving aside Calvin's idiolectal explanation of how objects either remain at rest or continue to move at a constant velocity unless acted upon by an external force, there are seven or eight main ways to make new English words:

- you can simply borrow words from other languages

- you can make compounds, combining existing nouns, verbs, adjectives and prepositions in many of the possible permutations of these word classes

- you can convert words from one class to another - nouns into verbs, verbs into nouns, adjectives into nouns, adjectives into verbs, prepositions into verbs (down a beer, up the ante), prepositions into nouns (life's ups and downs), conjunctions into nouns (ifs and buts), etc. If there is no change of form involved, linguists call this "zero derivation" 
- you can exploit the standard productive rules or schemas of English morphology or word-formation, using affixes (prefixes and suffixes), as in embiggen, misunderestimate, prehab, recombobulation area and truthiness, and neoclassical combining forms, as in hypermiling and omnishambles (I will return to these examples below)

- if trying to amuse highly educated people, you can also play with exclusively Greek and Latin roots, and invent sesquipedalian words like alogotransiphobia, anatidaephobia and dontopedology

- you can abbreviate a string of words into an acronym, for example WYSIWYTCH, from 'what you see is what your theory can handle' (Denison 2010: 105), a 'word' that should be brought to the attention of all linguists and scientists

- you can create new meanings by changing part of an existing word as a pun, or make portmanteau words by combining elements and meanings of two or more words into a single one, as in adorkable, googlegänger, metrosexual, nonebrity and refudiate

- you can invent genuinely new words, preferably cromulent ones, using the available sounds of the language.

As indicated by the examples above (most of which readily came to mind when I started writing this article), most people are more likely to notice what Mair (2006: 37) calls "curiosities, coined tongue in cheek and propagated as passing fads, especially in the media" than more mundane neologisms. Words with a 'surprisal' value are salient and easier to memorize and recall, which explains the many amusing words to be found in lists of the most creative words of the year. Other new words, or new metaphorical meanings of old words, which appear in tandem with new objects or activities during a speaker's lifetime - e.g. app, blog, broadband, browser, cloud, cookie, modem, mouse, notebook, tablet, virus, website, wi-fi, etc. - are more likely to be taken for granted; snailmail is more striking as a lexical innovation than email, googlegänger than google.

Cromulent was coined by David X. Cohen, one of the writers of The Simpsons, in 1996. When a schoolteacher learns that the Springfield town motto is "A noble spirit embiggens the smallest man," she says that she'd never heard the word embiggen before moving to Springfield. Another teacher replies "I don't know why; it's a perfectly cromulent word." Later in the same episode (Lisa the Iconoclast), Principal Skinner says of Homer's audition for the role of town crier, "He's embiggened that role with his cromulent performance." Thus cromulent would appear to mean appropriate or acceptable or more than acceptable. Embiggen clearly means to make something larger or better, and might be seen as the contrary of belittle, which was coined by Thomas Jefferson in his book Notes on the State of Virginia (1785), meaning to make something seem less valuable or important. Although embiggen was invented by Daniel Greaney, a writer for The Simpsons, like a great many coinages it had also been invented before, in this case in the antiquarian literary journal Notes and Queries in 1884, by a correspondent complaining about ugly new slang, who asks rhetorically, quoting Acts 
5.13, "Are there not, however, barbarous verbs in all languages? $\dot{\alpha} \lambda \lambda$ ' $\dot{\varepsilon} \mu \varepsilon \gamma \alpha \dot{\alpha} \nu v \varepsilon \varepsilon v$

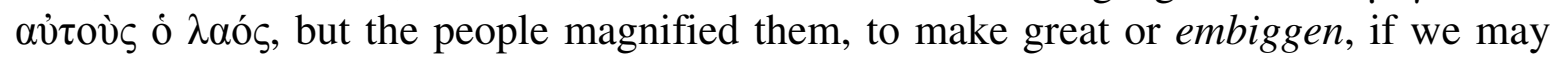
invent an English parallel as ugly." It is not immediately clear why he considers $\dot{\varepsilon} \mu \varepsilon \gamma \alpha \dot{\lambda} v v \varepsilon v$ (emegalynen) - a word quite widely used in Classical Greek - to be ugly, or why he feels the need to coin embiggen. ${ }^{1}$ Yet ugly or not, both embiggen and cromulent were taken up by some Simpsons' fans and are currently used here and there. Embiggen has even been used by string theorists in serious scientific journals.

I describe cromulent as a genuinely new word because its base doesn't hint at a preexisting meaning - unlike, for example, Rowling's muggle, which has echoes of both mug - "a stupid or incompetent person; a fool or simpleton; a gullible person, a dupe," and muggins or muggings, "a fool, a simpleton ... a name applied to a person who is duped, outwitted, or taken advantage of, or who has acted foolishly on some occasion" $(O E D)$. Cromulent also sounds English: there are a large number of English words beginning with cro- (and crom turns out to be a Middle English variant spelling of both cram and crumb, as well as a dialect word meaning crooked), a few (Latinate) adjectives ending with -lent (including pestilent, violent and, more pertinently here, excellent), and a lot of adjectives ending with -ulent, from the Latin -ulentus, usually meaning 'abounding in' or 'full of' (opulent, fraudulent, truculent, virulent, etc.).

The other words listed above which use standard English affixes are of various origins. Truthiness was coined by the American television comedian Stephen Colbert, and later defined by the American Dialect Society (hereafter ADS) - which made it their "Word of the Year" for 2005 - as "the quality of preferring concepts or facts one wishes to be true, rather than concepts or facts known to be true." The word was immediately picked up by journalists, and widely discussed on political and news programmes. (Unsurprisingly, it is also in the $O E D$ with a different sense: an obscure variant of truthy, meaning truthfulness, used in 1824.) Misunderestimate is a famous 'Bushism' from a speech in 2000, which took on a life of its own when it was ridiculed in the press; the President probably just meant underestimate, unless he really meant to say that people underestimated him without meaning to. Prehab - pre-emptive enrolment in a rehab facility to forestall or prevent the relapse of an abuse problem was the ADS's most creative Word of the Year in 2010. Recombobulation area is a joke from Mitchell International Airport in Milwaukee, consisting of a few chairs (and a big sign) just past a security checkpoint, where people can put their shoes, jackets and belts back on and repack their laptops and liquids. It is clearly a back-formation from discombobulate, a jokey American verb meaning to disturb, upset, disconcert or confuse, and was chosen by the ADS as the most creative neologism of 2008.

While -ness, mis-, pre- and re- are standard, and very productive, English affixes, hyper- and omni- are better thought of as neo-classical combining forms. Hypermiling, meaning the attempt to maximize gas (petrol) mileage by making fuel-conserving adjustments to one's car and one's driving techniques, was chosen by Oxford Dictionaries as its US Word of the Year in 2008. Omnishambles was Oxford Dictionaries' UK Word of the Year in 2012, and means a situation in total disorder that has been hopelessly mismanaged, full of blunders and miscalculations. It was coined by 
Tony Roche, one of the writers of the satirical television series The Thick Of It, and soon picked up by viewers and, importantly, British opposition politicians. It was followed by the short-lived Romneyshambles, after the US presidential candidate Mitt Romney tactlessly criticized London's preparations for the Olympic Games.

Alogotransiphobia was invented jointly in 1972 by the novelist George V. Higgins and two friends of his in Washington, a journalist and a publican, and means "the fear of being caught on public transportation with nothing to read." It hasn't really been institutionalized in the language, but it is listed in Dickson (2014: 19), after which it was taken up by many reviewers and bloggers. Anatidaephobia is a relatively wellknown joke word from Gary Larson's The Far Side cartoon strip, meaning an irrational fear that somehow, somewhere, a duck is watching you, using the Latin name for the biological family of birds that includes ducks, geese and swans, and phobia, an established English word of Greek origin; as Bauer (2001: 70) points out, "there is a rather fuzzy borderline between neo-classical compounding and affixation in English." Dontopedology, meaning to have a tendency to put one's foot in one's mouth, or make embarrassingly inappropriate remarks, is attributed to Prince Philip, the Duke of Edinburgh, and is still regularly used by journalists - largely when writing about Prince Philip - though it now has to compete with the equally playful but less classicalsounding foot-in-mouth disease. This last example (playing on foot-and-mouth disease, a virus that can affect cloven-hoofed animals) might almost be seen as an example of recategorization (Kastovsky, 1986: 595): forming a word as a condensed alternative to a longer syntactic description. ${ }^{2}$

The portmanteau words (a term invented by Lewis Carroll in 1871 in Through the Looking-Glass) have had various degrees of success. Metrosexual, a noun coined by the British journalist Mark Simpson to describe an overly fashion-conscious, city-dwelling, heterosexual male, was the ADS's Word of the Year in 2003, and gets nearly 1 million Google hits. Googlegänger, from Google and the German loanword Doppelgänger, meaning someone else with your name who shows up when you egosurf or google yourself, was the ADS's most creative word of 2007. Nonebrity, a celebrity nonentity, someone who manages to achieve and maintain celebrity status despite having done nothing to merit it, was one of a long list of Words of the Year in Susie Dent's (2008) book of that name. Refudiate, a verb coined by Sarah Palin, loosely meaning to reject and clearly an accidental blend of refute and repudiate, became the New Oxford American Dictionary's Word of the Year for 2010 - and the ADS's most unnecessary word. Adorkable, a blend of adorable and the slang word dork, meaning to be socially inept in an endearing way, had been around for a few years when it was popularized in 2011 by the American sitcom New Girl, and is now in the Collins English Dictionary. ${ }^{3}$

\section{Who?}

The examples of neologisms above suggest that today it is largely screenwriters and journalists who introduce words into the language, as well as the inventors of technological wonders such as Google, Wikipedia, Facebook, Twitter and the like (and 
- unwittingly - Republican Party politicians). Thus the entertainment and news media seem to have supplanted Literature with a capital L as the prime source of new words, as traditionally it was words from famous, widely-read, canonical authors that were taken up by readers (and other writers) and diffused in the speech community.

As is well-known, about 1500 words are first recorded in Shakespeare's plays, and as Lukas Erne (2013) has persuasively argued, Shakespeare almost certainly wrote many of his plays with a readership in mind, as well as the theatre audience. He didn't necessarily invent all 1500 - he may just have been the first famous writer to use them in print - but he probably invented most of them, by changing nouns into verbs and verbs into adjectives, adding prefixes and suffixes, joining words that had never previously been used together, and coining wholly original words. Nouns first found in Shakespeare include assassination, evasion and tardiness; adjectives include critical, deafening, hostile, inauspicious, laughable, suffocating and unmitigated; verbs include bedazzle, dwindle, embrace, enthrone and impede. Cromulent words found in Shakespeare which did not pass into common use include appertainments, attasked, conspectuity, defunctive, dispunge, enacture, ensear, exsufflicate, immoment, imperceiverant, intrenchant, irregulous, oppugnancy, relume, reprobance and rubious.

There often seems to be something of a correlation between writers' canonical status and the number of words for which they provide the first evidence. According to the Online OED, almost 2000 previously unrecorded words are to be found in the writings of Chaucer (but of course we only have a limited number of Middle English texts), over 600 in Coleridge, over 500 in Jonson, Milton, Sidney and Spenser, over 300 in Donne and Dryden, over 200 in Byron, Dickens and Richardson, over 100 in Defoe, George Eliot, Fielding, Johnson, Keats, Marlowe, Pope, Shelley, Swift and Tennyson, more than 50 in Emerson, Hardy, Joyce, Melville, Poe, Sterne, Twain and Wordsworth, slightly less than 50 in Austen and Charlotte Brontë, and so on; this list of names gives you a large part of the syllabus of degree courses on British and American literature.

There is, of course, some circularity to this argument: it is because the works of these writers are well-known that dictionary compilers read them. But ever since dictionaries began to be written, works of literature have existed alongside many nonfiction books, newspapers, journals, etc., so we can assume that many words may indeed have first been used in writing by the authors in question, at least for the past 200 years. Whether they coined them or merely used words they had heard in everyday speech is another matter; given the relatively formal nature of writing over most of its history, there is often a time-lag between words and constructions being used in speech and appearing in writing. On the other hand, it must also be remembered that the $O E D$ is a historical dictionary which includes many short-lived words, in particular many Latinate ones, that were only ever used by a single writer, sometimes trying unsuccessfully to replace an existing word. This particularly happened in the 16th and 17 th centuries when there was a vogue for Latin-sounding words, supposedly to raise the status of the English language, although these were criticized by plainer folk as "ink-horn terms" (from the inkwells made of horn that writers dipped their quills in). 
Another, completely different category of people who frequently coin words (but without getting them diffused and institutionalized) are nonnative speakers. Such speakers have traditionally been described as learners or users of English as a foreign language (EFL) and their coinages have been considered as errors resulting from the imperfect learning to be expected in a second language (L2). There is a huge array of concepts in second language acquisition (SLA) theory designed to explain the existence of such errors: interference, L1 transfer, substratum influence, fossilization, interlanguage, imposition, source language agentivity, congruence, relexification, etc. Speakers carry over features from their L1 into their version of the L2, making erroneous analogical inferences, simplifying, over-generalizing, under-differentiating, and so on.

A more recent concept is that of English as a lingua franca (ELF), which Barbara Seidlhofer (2011: 7) defines as "Any use of English among speakers of different first languages for whom English is the communicative medium of choice, and often the only option." Spoken ELF generally differs from ENL (English as a native language) and contains a huge amount of linguistic variation and nonstandard lexicogrammatical and phraseological forms. As Ferguson (2009: 129) puts it, ELF should be viewed "as a fluid cluster of communicative practices where speakers draw on a wide, not clearly bounded range of linguistic features - some standard, some non-standard, and others not English at all (at least according to the conventional view)."

ELF clearly doesn't need to be the same as ENL. It is not part of any native 'target culture' in which particular ways of speaking and behaving are appropriate. Rather than imitating the norms of native English speakers, ELF speakers (are said to, or recommended to) adopt ways of speaking which aid mutual intelligibility and successful communication. The proponents of ELF argue that it is different from but not inferior to ENL. Thus the difference between EFL and ELF is an attitude: EFL learners make mistakes (or errors); ELF users show a lot of variety. What is intrinsic to ELF is not any specific linguistic forms, but rather what Firth (2009: 150) calls the "lingua franca factor" - "the inherent interactional and linguistic variability that lingua franca interactions entail" - and the "lingua franca outlook" on language that ELF users adopt.

Anna Mauranen describes the variation to be found in ELF in terms of "shaky entrenchment" or "fuzzy processing" resulting from restricted (and varied) input. She states that "the nature of processing is fuzzy in most areas of cognition, including speech perception and production" (2012: 41), and that "a complex environment like ELF" - generally involving different speakers with different English usages in every single interaction - "seems to require stretching the tolerance of fuzziness wider than usual" (2012: 42). L2 speakers have "less deeply entrenched memory representations" (2012: 37) than L1 users, and so produce approximate (or deviant, or creative) words such as anniversity, curation, dictature, elevative, importancy, lightful, overbridging, removement, slowering, and womanist (all from VOICE), and addictation, assaultment, instable, interpretee, maximalise, plagiate, unuseful and visiblelise (all from ELFA). ${ }^{4}$ In the two ELF corpora, most of these words are used by speakers showing a high level of competence and fluency in English. As Mauranen puts it, ELF speakers use words and 
phraseological units "in ways that do not quite match the target," but - importantly although they "tend to get them slightly wrong," they "also get them approximately right” (2012: 144).

Unsurprisingly, many of these nonstandard words result from standard wordformation processes, as described, e.g., in Bauer (1983) and Plag (2003). Suffixation, conversion and modification, or what Mauranen (2012: 126) calls the "extension of productive derivational principles beyond their conventional boundaries," can be seen in the approximate or invented verbs intersectioning, resoluting, satisfactionate, securiting and successing; the nouns analytism, assimilisation, competensity, controversiality, interventing, militarians and paradigma; and the nonstandard adjectives deliminated, devaluarised, disturbant, emperious, femininised, proletariatic and strategical. In VOICE and ELFA there are backformations such as colonisators, introducted, presentate, registrate and standardisate, and truncations like automously, categoration, decentralation, manufacters and significally, as well as what look like borrowings from the L1 (or possibly L3, etc.) such as dictature, instable, performant and phenomen.

Most of these nonstandard forms only appear once in ELF corpora (and so are what corpus linguists call hapaxes or hapax legomena $),{ }^{5}$ and are clearly nonce words spontaneous creations by a speaker, coined for a particular purpose on a specific occasion - rather than neologisms destined to become institutionalized in the language. Of course at the point of utterance no speaker ever knows whether a nonce word will become a neologism, but clearly many of the "slightly wrong" ELF coinages would not be coined, or need to be adopted, by native English speakers because the existence of a synonym blocks the use of a newly derived rival form, according to the constraints of mental processing and storage (see Plag, 2003: 63-68). Moreover, most of these words seem to go largely unnoticed by the hearers, who neither accommodate to them by repeating them, nor attempt to correct them. Given that hearers usually prospect and make guesses about what is coming next, rather than listening carefully to each word, it is quite likely that many of them fail to even notice nonstandard forms, especially if they also use lexical approximations themselves. Indeed, when they encounter a linguistic anomaly, ELF interlocutors are said to "let it pass" or "make it normal": faced with problems in understanding the speaker, they let the unknown or unclear word or utterance go by on the assumption that it will either become clear or redundant as talk progresses (Firth 1996).

Widdowson (2003: 58) points out that the "inadvertent errors" of language learners occasionally resemble "the nonconformist usage" of adventurous authors such as Carroll, Joyce, Cummings and Achebe, which he describes as "evidence of the existence of ... the virtual language, that resource for making meaning immanent in the language which simply has not hitherto been encoded" (2003: 48-9). Seidlhofer (2011: 120) takes up this concept, describing ELF as "a different but not a deficient way of realizing the virtual language, or playing the English language game," but avoids the notion of error: instead of restricting themselves to the realizations of native English speakers, ELF users exploit unused latent potentialities of English morphology, syntax 
and phraseology. Standard Native English "represents what has been encoded, but not what can be" (2011: 117), and "to be creative is to exploit the constitutive rules of the virtual language but to do so without fully adhering to established regulative conventions, quite simply because those conventions are not necessarily appropriate to communicative purpose" in lingua franca communication (2011: 124).

It remains a matter of opinion, however, whether ELF coinages should be described in terms of creativity, or merely involuntary approximation resulting from shaky entrenchment or imperfect learning. ${ }^{6}$ It also turns out that a great many ELF 'coinages' have in fact been used before - in the actual rather than the virtual language. For example, a number of words in VOICE which Pitzl et al. (2008) classify as "lexical innovations" and "coinages" are recorded in more comprehensive dictionaries than the one they used - as they readily concede (2008: 39). The OED includes the following, with the dates of the first recorded uses: conformal 1647, cosmopolitanism 1828, devaluated 1898, devotedness 1668 , examinate 1560, forbiddenness 1647 , importancy 1540 , increasement (encreasement) 1509, non-transparent 1849, pronunciate 1652, reenrol 1789, re-send 1534, and urbanistic 1934. While some of these words are wholly obsolete in native English, others are still used. Forbiddenness, for example, which gets about 16,000 hits on Google, ${ }^{7}$ certainly fills a lexical gap, but it first filled it a long time ago, even if individual ELF speakers (not to mention native speakers) feel that they are coining it online and ad hoc each time it is used today.

Yet whether they should be thought of as creative coinages or imperfect approximations, the foregoing lists of on-the-spot nonce-formations by ELF speakers remind me of the following list of words: curvate, familistic, habitude, producement and rememorating. All of these - along with dit, gloam, rummers, scrab and shipponcome from Vladimir Nabokov's (1964) English translation of Pushkin's 'novel in verse' Eugene Onegin, and were criticized by Edmund Wilson (1965) as the "entirely inappropriate" use of "rare and unfamiliar words," if not "actual errors in English" (see Remnick 2005). ${ }^{8}$ Of course, Nabokov was a nonnative speaker of English, but he is anything but an unknown user of English as a lingua franca (the adjective Nabokovian is in the $O E D$, along with his coinage nymphet), and in his translation of Onegin he knew exactly what he was doing, as can be seen from his replies to his critics (Nabokov $1965 ; 1966)$. But the interesting thing about some of the words that Nabokov dredged out of the OED (or wherever) - particularly familistic, habitude and producement - is that they look exactly like the kind of approximations made by ELF speakers, which once again suggests that many of these 'coinages' may not in fact be new at all, but also that if they were used by an experimental author rather than a speaker of English as a lingua franca they might be admired (though not by Edmund Wilson) as innovative uses of the virtual language rather than dismissed as errors. 


\section{Creativity and productivity}

The question remains whether the coiners of words - both famous and unknown, both native and nonnative speakers - are actually being creative, or whether their usages should be attributed to morphological productivity: to what were traditionally called word-formation rules, but which can also be described as schemas - ways of representing concepts and abstractions stored in the memory, in this case bound morphemes or affixes, conventionalized form and meaning pairings which occur with sufficient frequency for speakers to form a generalization over their instances of use (Goldberg 2006; Booij 2010). ${ }^{9}$ Crystal (2003) defines productivity as "the creative capacity of language users to produce and understand an indefinitely large number of sentences" (2003: 374), and creativity as "the capacity of language users to produce and understand an indefinitely large number of sentences, most of which they will not have heard or used before. Seen as a property of language, it refers to the 'open-endedness' or productivity of patterns" (2003: 116). There is quite a lot of overlap here...

Native speakers of a language like English have internalized (after making generalizations) a number of word-formation processes that allow them to form new words both consciously and unconsciously, or intentionally and unintentionally, although as Plag (1999: 14) insists, unintentionality is a vague and nonoperationalizable concept: "Some speakers have a higher level of awareness of the manipulation of linguistic signs than others," so that "what goes unnoticed by one speaker may strike the next as unusual." And as Bauer (2001: 68) points out, a word can be "coined unconsciously, but then picked up in a mental scan of the speaker's own words." Furthermore, people do not always know whether words made by way of highly productive rules or constructions actually exist or not (for a speech community rather than for the individual speaker), and subjects in experiments tend to consider potential words to be actual ones (Plag, 1999: 8).

For example, native speakers of English are likely to know intuitively that -ize is currently a very productive verbalizing suffix, and that -ify and -ate are much more restricted (although in any given case, the productivity or applicability of a rule or process may be constrained by various phonological, morphological, semantic and syntactic properties of the elements involved). They will also have a subconscious awareness that virtually every verb ending in -ize can be turned into a noun with -ation, and that -ion can be added to verbs ending in -ate. Thus omnishamb(e)lize and omnishamb(e)lization are more likely than omnishamblify and omnishamblification, while omnishamblate sounds highly improbable. Native English speakers will probably also know intuitively that the prefixes en- and em- (sometimes accompanied by the suffix -en) are now "practically dead" (Plag, 1999: 117), which is why the coinage embiggen was striking in the 1990s. ${ }^{10}$

Examples of productive nominalizing suffixes in present day English include -ness (for all bases) and -ity (for Latinate bases). There will be a number of single occurrences (hapaxes) of words with these endings in any large corpus, some of which are likely to be neologisms, while many others will just be rare or infrequent words. ${ }^{11}$ On the other 
hand, there will be very few neologisms with the suffix -ment, which is hardly ever used today by native speakers to create new nouns, although it was formerly hugely productive, notably with French stems after the Norman Conquest and with both Latinate and Germanic stems until the mid-19th century (Bauer, 2001: 6-8; Hilpert, 2013: 110-54). ${ }^{12}$

This goes to show that the productivity (or indeed the availability) of affixes or schemas (for native speakers) can change diachronically, especially if they are in direct competition with others, and that the productivity of one process can restrict the productivity of another. Contemporary nonnative corpora, on the contrary, show various coinages with -ment, and Pitzl et al. (2008: 32) argue that some ELF speakers use this suffix not to change the word class of the base form but to emphasize the original class and thereby increase clarity: e.g. assaultment and increasement are clearly nouns, whereas assault and increase could be either nouns or verbs. Similarly, characteristical and linguistical emphasize adjectivalness, as characteristic and linguistics are also nouns. If these uses really are deliberate rather than accidental, the label creativity (rather than productivity) does seem appropriate.

All of this suggests that native speakers have a detailed knowledge of wordformation processes or constructional schemas, which become "entrenched" (Langacker 1987) or routinized or automatized as a result of repeated input, with every repetition strengthening their entrenchment in the mind and leaving a neuronal trace that facilitates their re-use. This implies that frequency of usage is an important part of linguistic knowledge (Bybee, 2007; 2010). Many nonnative speakers, on the contrary, have a shakier or fuzzier knowledge of such processes, and sometimes devise their own (nonnative) word-formation rules. By definition, they lack the exposure to a language that comes from growing up in a specific speech community, and so do not share native speakers' internalized, subconscious, procedural knowledge of the 'rules' or constructions of the language they grew up with, or their awareness of the limits of acceptability and productivity. Nonnative speakers are generally less attuned to the subtleties of (native) constructional schemas. For example, ELFA and VOICE include, among others, the negative forms disbenefits, discrease, injust, inofficial, intransparency, uncapable, undirectly, unpossible, unrespect and unsecure, which seems to indicate that many ELF speakers employ the simplification strategy "use the negative prefix of your choice. ${ }^{\prime 13}$ Nonnative speakers are also less likely to be sensitive to changing patterns in the relative productivity of these constructions, and so may be unaware of the current non-productivity of the -ment suffix in native English. Consequently nonstandard ELF usages often appear more creative (or unusual, or just plain wrong) to the native ear than native speakers' own coinages resulting from regular, entrenched productive processes.

Thus native speakers' neologisms wholly formed by way of frequently used constructional schemas would seem to be more a matter of productivity than creativity. The latter term seems better suited for non-rule-governed coinages which clearly go beyond established productive word-formation processes, such as wholly new words, clever blends and portmanteau words, acronyms, novel uses of Greek and Latin forms, 
and useful compounds (such as Shakespeare's barefaced, birthplace, earthbound, evenhanded, lack-lustre, short-lived, snail-paced, time-honoured and watchdog ). There are also the "many journalistic formations which are coined to attract attention" (Bauer, 2001: 23), and "playful formations" (2001: 56), used more for their phonetic than their semantic properties, which tend to occur "only in poetry or poetic and/or highly literary prose" or "in headlines" (2001: 57). Any rule-breaking or rule-changing innovation can in turn be imitated by analogy, after which further coinages exploiting the same pattern are once again more a matter of rule-governed productivity.

\section{Diffusion}

The last question is how neologisms get diffused - or not. There are occasional cases of words that are not in fact new, but which have a local or technical meaning, that suddenly become known to hundreds of millions of people in a very short space of time. The word chad, or more technically hanging chad - the incompletely-punched holes in voting cards which falsified the result of the 2000 US Presidential election - and the Japanese word tsunami, which dominated the news after the Pacific earthquake in 2004, literally spread around the world from one day to the next. Other words took slightly longer to be disseminated internationally, including the Japanese $s u d o k u$, which was a global craze in 2005; slumdog, a derogatory term for the children living in Mumbai's slums which was popularized by a film in 2008; and vuvuzela, the little monotone plastic trumpet that made a horrible noise throughout the World Cup in South Africa in 2010.

These were mostly necessary words for labelling new objects or events. It is usually argued that electronic media are not very instrumental in diffusing less necessary linguistic innovations (Trudgill, 1986: 40; Britain, 2002: 609), but speakers can imitate or copy influential individuals on television and radio, in films, etc. Yet the vast majority of new coinages do not leap out at you from newspapers or news programmes, and generally require luck to be diffused throughout a large speech community. The fate of most new words probably depends on their being picked up by influential early adopters - popular people with many contacts and extensive weak ties in large, loose social networks - who introduce new words to large numbers of people, some of whom also begin to use them (Milroy \& Milroy, 1985). But while these are necessary conditions for the diffusion of neologisms, they are clearly not sufficient ones. There is probably a critical threshold for new words or expressions to be recognized and stored in the mental lexicon, after which every repetition strengthens their entrenchment (Bybee 2007). Necessary words, such as the first lexicalizations of new objects or concepts that fill a gap in the language (browser, website, email) are likely to spread and quickly reach this threshold. Whether less necessary neologisms, particularly topical humorous ones, get diffused is essentially a matter of chance; some of them especially those that are designed to attract attention - do indeed end up embiggening the language, cromulently or otherwise, but most of them do not. Chumble spuzz! 


\section{Notes}

1. Notes and Queries: A Medium of Intercommunication for Literary Men, General Readers, Etc. Sixth Series, Volume Tenth, July-September 1884, p. 135 . Online at https://archive.org/details/s6notesqueries10londuoft. I came across cromulent in a football blog, googled it, and found most of the information in this paragraph on the Wikipedia page on Lisa the Iconoclast. My thanks also go to my Ancient Greek correspondent, Neil Forsyth.

2. A more standard example of recategorization would be top-scorer rather than something like "the person who scored more than anybody else," a word that can in turn be converted into the verb to top-score, the adjective top-scoring, etc. Syntactic recategorizations are often unpopular with the kind of people who like to decry new words as barbarisms or abominations; a notable example in English in my youth was the use of hopefully to adverbialize the phrase "it is to be hoped that," a usage that has now hopefully become fully acceptable.

3. Quite a lot of portmanteau words are coined - www.wordspy.com lists, among others, adultescent, anticipointment, approximeeting, banalysis, boomsayer, daycation, entreprenerd, gayborhood, nico-teen, renoviction, scanxiety, slanguist, testilying, trustafarian, voluntourism and webisode - but very few of them become institutionalized in the language.

4. VOICE is the Vienna-Oxford International Corpus of English; http://www.univie.ac.at/voice/. ELFA is the English as a Lingua Franca in Academic Settings corpus, recorded at the universities of Helsinki and Tampere in Finland; http://www.helsinki.fi/englanti/elfa/elfacorpus.

5. Exceptions to this are some frequently used regularized past tense forms (losed, teached, etc.), and the widespread use of explicit prepositional verbs, with prepositions that would be considered redundant in native English, such as contact with, discuss about, emphasise on, mention about, phone to, reject against, return back, etc. (Seidlhofer 2011: 145ff).

6. Exceptions to this are words that genuinely fill semantic gaps; examples from ELFA include visiblelise, meaning to make something visible to other people, and interpretee, a person being interpreted; as Kastovsky (1986: 598) suggests - with an interesting use of "literally" - "in this century a critical mass was reached and the suffix [-ee] literally exploded." Elsewhere (MacKenzie 2014) I have called the habit of describing all nonstandard ELF usages as examples of innovation and creativity the "angelic interpretation" of ELF ... though it is perhaps worth recalling that until the mid-19th century the most common meaning of the German adjective englisch was "angelic" (Keller, 1994: 77-79)!

7. Google figures are unreliable, and forbiddenness only gets one hit each in the BNC (British National Corpus), http://corpus.byu.edu/bnc/, and COCA (the Corpus of Contemporary American), http://www.americancorpus.org/.

8. Among Wilson's "actual errors" is Nabokov's use of what he describes as "the archaic and poetic" form "to listen the sound of the sea" (translating slushat' shum morskoy), to which Wilson objects that "in English you have to listen to something." Nabokov (1966) riposted with examples from Byron's Don Juan - "Listening debates not very wise or witty," and Tennyson's "Ode to Memory" - "Listening the lordly music."

9. Goldberg (2006: 5) included morphemes in her inventory of constructions, or conventionalized form and meaning pairings, but Booij (2010: 15) insists that "morphemes are not linguistic signs, i.e. independent pairings of form and meaning. The minimal linguistic sign is the word. [...] bound morphemes form part of morphological schemas, and their meaning contribution is only accessible through the meaning of the morphological construction of which they form a part." 
10. There are only seven 20th century neologisms beginning with $\mathrm{em}$ - or $\mathrm{en}$ - attested in the $O E D$, and two ending with -en, compared with 284 -ize derivatives, 72 -ate derivatives, and 23 -ify words (Plag, 1999: 104, 271-3).

11. The larger a corpus, the more chance there is of words appearing more than once, but also the more scope for hapaxes, and indeed in large corpora, approximately $50 \%$ of the words (types rather than tokens) are hapaxes, as is predicted by Zipf's Law - a word's frequency is inversely proportional to its rank in the frequency table - and the shape of the curve this gives. The scope of productive rules or constructions is perhaps illustrated by the fact that while the $O E D$ only contains approximately 500,000 words (including 100,000 obsolete ones), the 100 million tokens in the BNC represent about 940,000 types (Plag, 2003: 50).

12. -hood is also now more or less unproductive, apart from witty literary creations like "The sound of the monsters of the river beginning the long journey to handbaghood broke out," from Terry Pratchett's Pyramids (1989), quoted in Bauer (2001: 67).

13. This is in contrast to native English speakers' implicit knowledge of remarkably complex word-formation rules for negative prefixes: see Plag (2003: 30-36).

\section{References}

Bauer, Laurie (1983): English Word-Formation. Cambridge: Cambridge University Press.

---- (2001): Morphological Productivity. Cambridge: Cambridge University Press.

Booij, Geert (2010): Construction Morphology. Oxford: Oxford University Press.

Britain, David (2002): "Space and spatial diffusion." In J.K. Chambers, Peter Trudgill and Natalie Schilling-Estes, eds., The Handbook of Language Variation and Change. Oxford: Blackwell, 603-637.

Bybee, Joan (2007): Frequency of Use and the Organization of Language. Oxford: Oxford University Press.

---- (2010): Language, Usage and Cognition. Cambridge: Cambridge University Press.

Carroll, Lewis (1871): Through the Looking-Glass, and What Alice Found There. London: Macmillan.

Crystal, David (2003, fifth edition): A Dictionary of Linguistics and Phonetics. Oxford: Blackwell.

Denison, David (2010): "Category change in English with and without structural change." In E. Closs Traugott and G. Trousdale, eds., Gradience, Gradualness and Grammaticalization. Amsterdam: John Benjamins, 105-128.

Dent, Susie (2008): Words of the Year. Oxford: Oxford University Press.

Dickson, Paul (2014): Authorisms: Words Wrought By Writers. New York: Bloomsbury.

Erne, Lukas (2013, second edition) Shakespeare as Literary Dramatist. Cambridge: Cambridge University Press.

Ferguson, Gibson (2009): "Issues in researching English as a lingua franca: a conceptual enquiry." International Journal of Applied Linguistics 19(2): 117-135.

Firth, Alan (1996): "The discursive accomplishment of normality: on 'Lingua Franca' English and conversation analysis." Journal of Pragmatics 26(2): 237-259.

---- (2009): “The lingua franca factor.” Intercultural Pragmatics 6(2): 147-170.

Goldberg, Adele E. (2006) Constructions at Work: The Nature of Generalization in Language. Oxford: Oxford University Press.

Hilpert, Martin (2013): Constructional Change in English: Developments in Allomorphy, Word formation, and Syntax. Cambridge: Cambridge University Press. 
Jefferson, Thomas (2002 [1785]): Notes on the State of Virginia. New York: Palgrave.

Kastovsky, Dieter (1986): "The problem of productivity in word formation." Linguistics 24(3): 585-600.

Keller, Rudi (1994): On Language Change: the Invisible Hand in Language, trans. Brigitte Nerlich. London: Routledge.

Langacker, Ronald W. (1987): Foundations of Cognitive Grammar, Volume 1: Theoretical Prerequisites, Stanford: Stanford University Press.

MacKenzie, Ian (2014): English as a Lingua Franca: Theorizing and Teaching English. London: Routledge.

Mair, Christian (2006): Twentieth-Century English: History, Variation, and Standardization. Cambridge: Cambridge University Press.

Mauranen, Anna (2012): Exploring ELF: Academic English Shaped by Non-native Speakers. Cambridge: Cambridge University Press.

Milroy, James and Leslie Milroy (1985): "Linguistic change, social network and speaker innovation." Journal of Linguistics 21(2): 339-384.

Nabokov, Vladimir (1965): "Letters: The Strange Case of Nabokov and Wilson." New York Review of Books, August 26.

http://www.nybooks.com/articles/archives/1965/aug/26/letters-the-strange-case-of-nabokovand-wilson/

---- (1973 [1966]): “Reply to my critics.” In Strong Opinions. New York: McGraw-Hill.

Pinker, Steven (2008): The Stuff of Thought. London: Penguin.

Pitzl, Marie-Luise, Angelika Breiteneder and Theresa Klimpfinger (2008): "A world of words: processes of lexical innovation in VOICE." Vienna English Working Papers 17(2): 21-46.

http://anglistik.univie.ac.at/fileadmin/user_upload/dep_anglist/weitere_Uploads/Views/views_0 802.pdf

Plag, Ingo (1999): Morphological Productivity: Structural Constraints in English Derivation. Berlin: Mouton de Gruyter.

---- (2003): Word-Formation in English. Cambridge: Cambridge University Press.

Pratchett, Terry (1989): Pyramids. London: Corgi.

Pushkin, Aleksandr Sergeevich (1991 [1837/1964]): Eugene Onegin: A Novel in Verse, 2 volumes, trans. Vladimir Nabokov. Princeton: Princeton University Press.

Remnick, David (2005): "The Translation Wars." New Yorker, November 7. http://www.newyorker.com/magazine/2005/11/07/the-translation-wars.

Rowling, J.K. (1997): Harry Potter and the Philosopher's Stone. London: Bloomsbury.

Seidlhofer, Barbara (2011): Understanding English as a Lingua Franca, Oxford: Oxford University Press.

Tolkien, J.R.R. (1937): The Hobbit, or There and Back Again. London: George Allen \& Unwin.

Trudgill, Peter (1986): Dialects in Contact. Oxford: Blackwell.

Widdowson, H.G. (2003): Defining Issues in English Language Teaching. Oxford: Oxford University Press.

Wilson, Edmund (1965): "The Strange Case of Pushkin and Nabokov." New York Review of Books, July 15.

http://www.nybooks.com/articles/archives/1965/jul/15/the-strange-case-of-pushkin-andnabokov/

All websites accessed 10 September 2014. 